\title{
PENGEMBANGAN SISTEM INFORMASI TEKNOLOGI PENGOLAHAN AIR (SITPA)
}

\author{
Oleh : \\ Heru Dwi Wahjono \\ Peneliti Pada Pusat Teknologi Lingkungan, BPPT
}

\begin{abstract}
Clean water needs and wastewater treatment will be a serious problem for industry especially for food industries. The packet information of applicable technology for water treatment and industrial waste handling that can support any development sector nowadays is needed by any kind of society especially for small and medium enterprise players. To face on globalisation, the computer and information technology will be used as an important tools for distributing the packet of technology from R\&D community to any kind of society through global network. By using the existing network infrastructure in the country, the packet information of technology will be distributed electronically specially to help group of small and medium industry. As pilot project, this activity chooses the tahu/tempe industry located in Semanan, Jakarta Barat for the industrial centre. By surveying the need of technology, we try to help craftsman to resolve their problem on clean water supply and industrial waste, so they can increase their product quality.
\end{abstract}

Katakunci: air bersih, limbah cair, sistem informasi, internet, hypertext, multimedia

\section{PENDAHULUAN}

\subsection{Masalah Air Bersih}

Pengadaan air bersih di Indonesia khususnya untuk skala yang besar masih terpusat di daerah perkotaan, dan dikelola oleh PAM. Namun secara nasional jumlahnya masih belum mencukupi dan dapat dikatakan relatif kecil yakni 16,08 \% (Supas 1995). Untuk daerah yang belum mendapatkan pelayanan air bersih dari PAM umumnya memakai air tanah (sumur), air sungai, air hujan, air sumber (mata air) dan lainnya. Dari hasil survey penduduk antar sensus (SUPAS) 1995, prosentasi banyaknya rumah tangga dan sumber air yang digunakan di berbagai daerah sangat bervariasi tergantung dari kondisi geografisnya. Secara nasional dapat dibuatkan grafiknya seperti gambar berikut :

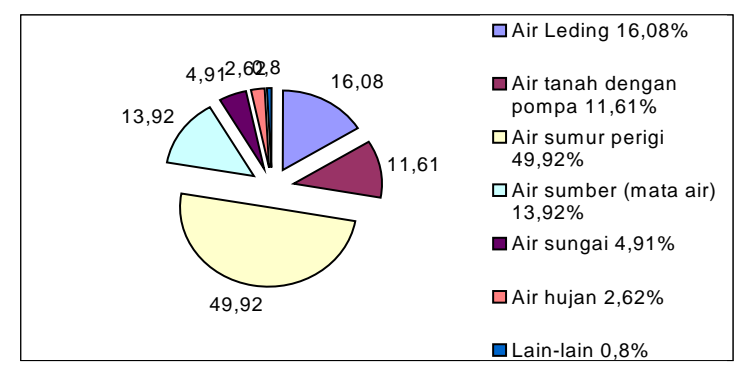

Gambar 1: Grafik Penggunaan Sumber Air.

Permasalahannya adalah sering dijumpai bahwa kualitas air tanah maupun air sungai yang digunakan kurang memenuhi syarat sebagai air minum yang sehat bahkan di beberapa tempat tidak layak untuk diminum. Air yang layak minum, mempunyai standar persyaratan tertentu yakni secara fisis, kimiawi dan bakteriologis. Jadi jika ada satu saja parameter yang tidak memenuhi syarat maka air tesebut tidak layak untuk diminum.

Masalah air bersih yang memenuhi syarat kesehatan tidak hanya dialami oleh masyarakat umum, tetapi juga sering dialami oleh masyarakat industri khususnya industri kecil dan menengah yang bergerak di dalam industri proses khususnya proses pengolahan makanan dan minuman serta proses yang selalu berhubungan dengan senyawa kimia. Masalah air bersih yang kurang memenuhi syarat tersebut sangat berpengaruh terhadap kualitas produk.

Sebagai contoh di dalam industri makanan dan minuman jika air yang digunakan kurang baik maka produk yang dihasilkan juga kurang baik, apalagi jika air yang digunakan tidak steril maka produk yang akan dihasilkan dapat terkontaminasi oleh mikroorganisme patogen yang mana dapat membayakan konsumen.

\subsection{Masalah Pencemaran Lingkungan}

Masalah pencemaran lingkungan di kota besar, telah menunjukkan gejala yang serius, khususnya masalah pencemaran air. Penyebab dari pencemaran tadi tidak hanya berasal dari buangan industri saja, tetapi juga yang tidak kalah memegang andil baik secara sengaja atau tidak adalah masyarakat itu sendiri. Yakni akibat air buangan rumah tangga yang jumlahnya 
makin hari semakin besar sesuai dengan tingkat perkembangan penduduk maupun perkembangan kota.

Air limbah kota-kota besar di Indonesia secara garis besar dapat dibagi menjadi tiga yaitu air limbah industri dan air limbah domestik yakni yang berasal dari buangan rumah tangga dan yang ke tiga yakni air limbah dari perkantoran dan pertokoan. Saat ini pencemaran akibat limbah domistik telah menunjukkan tingkat yang cukup serius. Selain itu sumber pencemaran yang potensial adalah air limbah yang berasal dari kegiatan industri/UKM.

Untuk industri besar, masalah air limbah mungkin dapat diatasi oleh pihak industri sendiri karena mempunyai modal yang cukup, tetapi untuk masalah limbah dari industri kecil dan menengah yang jumlahnya sangat banyak sekali tersebut belum tersentuh sama sekali. Sebagai contoh industri kecil tahu-tempe. Limbah industri ini dapat menimbulkan pencemaran yang cukup berat karena mengandung polutan organik yang cukup tinggi. Dari hasil penelitian, konsentrasi COD di dalam air limbah tahu-tempe cukup tinggi berkisar antara 7.000-10.000 ppm, serta mempunyai keasaman yang rendah yakni $\mathrm{pH}$ 45. Dengan kondisi seperti tersebut di atas, air limbah industri tahu-tempe merupakan salah satu sumber pencemaran lingkungan yang potensial.

\subsection{Informasi Teknologi Pengolahan Air}

Pada dasarnya masalah yang sering dihadapi oleh usaha kecil dan menengah adalah masalah penyediaan air bersih dari sumber air baku yang tidak bersih dan masalah pengolahan air limbah agar tidak mencemari lingkungan. Oleh karena itu untuk menanggulangi masalahmasalah ini mereka membutuhkan paket informasi bagaimana menyediakan air bersih untuk keperluan hidup dan usaha mereka, atau bagaimana mengolah air limbah yang dihasilkan dari industri mereka.

Beberapa teknologi pengolahan air bersih dan air limbah yang dapat diterapkan untuk membantu usaha kecil dan menengah antara lain adalah :

\section{$>$ Teknologi Pengolahan Air Bersih :}

1. Alat pengolahan air bersih dengan saringan pasir lambat upflow.

2. Alat pengolahan air sumur siap minum.

3. Filter untuk menghilangkan zat besi dan mangan dalam air.

4. Filter untuk menghilangkan kesadahan.

5. Teknologi pembuatan air mineral.

6. Alat pengolahan air asin menjadi air minum dengan sistem osmosis balik.

7. Alat pengolahan air gambut.

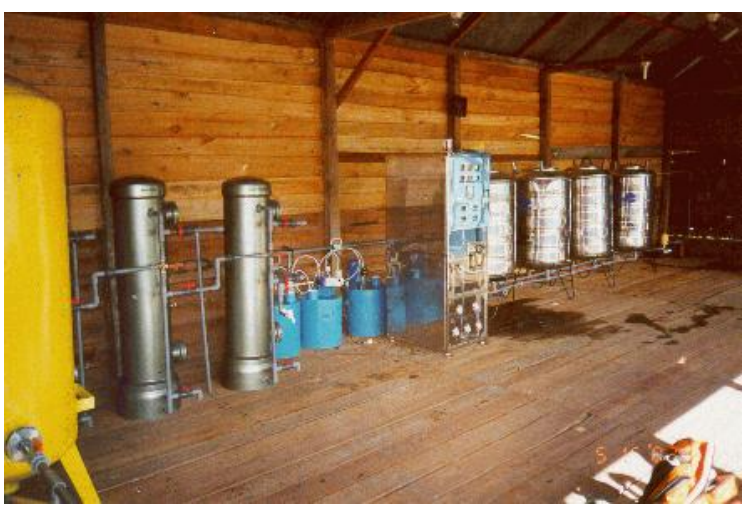

Gambar 2 : Teknologi Pengolahan Air Bersih.

\section{Teknologi Pengolahan Air Limbah :}

1. Pengolahan air limbah rumah tangga dengan sistem biofilter anaerob-aerob.

2. Pengolahan air limbah rumah sakit.

3. Pengolahan air limbah tahu/tempe.

4. Pengolahan air limbah elektroplating.

5. Pengolahan air limbah penyamakan kulit.

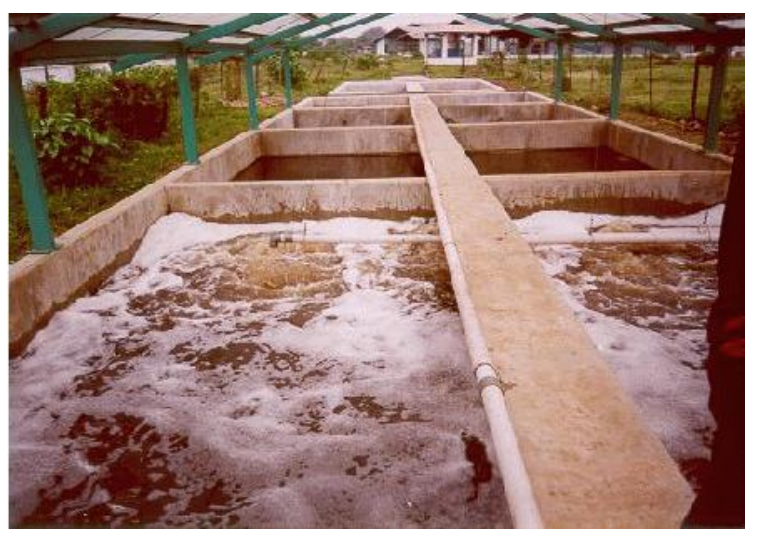

Gambar 3 : Teknologi Pengolahan Air Limbah.

Untuk mempermudah para usaha kecil dan menengah dalam memperoleh informasi paket teknologi pengolahan air, maka penyajian dan penyebaran informasi paket teknologi ini dapat dilakukan dengan memanfaatkan teknologi sistem informasi hypertext dalam jaringan global internet. Dengan memanfaatkan teknologi ini, maka para usaha kecil/menengah, para penyedia teknologi, yayasan pemberi modal, dan yang lain-lainnya akan terjaring sehingga mempermudah mereka dalam melakukan aktifitas industri dan bisnis mereka.

Paket teknologi yang telah ditulis dalam format hypertext disajikan melalui komputer server yang akan dikelola oleh unit kerja teknis, sehingga pos informasi dan pelayanan teknologi yang ada di sentra industri dapat mengakses langsung informasi tersebut. 


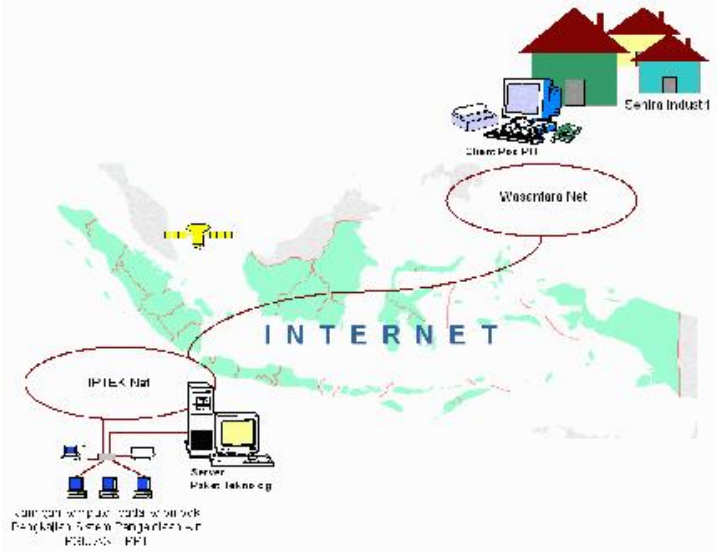

Gambar 4 : Penyebaran Paket Informasi Teknologi.

\section{TUJUAN DAN SASARAN}

Kegiatan ini bertujuan memberikan paket informasi teknologi pengolahan air secara elektronik untuk membantu usaha kecil/menengah dalam mengatasi masalah air bersih dan limbah cair. Adapun sasaran kegiatan ini adalah menyediakan beberapa paket teknologi pengolahan air bersih dan limbah cair.

\section{METODOLOGI}

Metodologi pelaksanaan pengembangan sistem dilakukan dengan beberapa tahapan metodologi, yaitu :

1. Identifikasi kebutuhan informasi teknologi pengolahan air pada sentra industri.

2. Pendefinisian paket teknologi pengolahan air yang bersifat tepat guna.

3. Pemilahan paket teknologi pengolahan air berdasarkan kegiatan industri.

4. Pengumpulan dokumen dan referensi penunjang.

5. Penulisan/editing naskah paket teknologi secara elektronik.

6. Instalasi hardware dan software untuk komputer yang dijadikan sebagai server.

7. Pembuatan RDBMS dan database engine.

8. Instalasi data paket teknologi ke dalam komputer server dan uji coba.

9. Instalasi komputer pada pos informasi pelayanan teknologi di sentra industri

\section{PELAKSANAAN KEGIATAN}

\subsection{Identifikasi Kebutuhan Informasi Teknologi Pengolahan Air}

Identifikasi kebutuhan teknologi dilakukan dengan mengadakan survai ke beberapa pusat pengerajin tahu/tempe di antaranya di daerah Semanan, Jakarta Barat, pusat industri kecil LIK di Semarang dan pabrik kecap group Indofood di Semarang. Kegiatan identifikasi kebutuhan teknologi di Semanan dilakukan terhadap beberapa pengerajin dan para pengelola KOPTI.

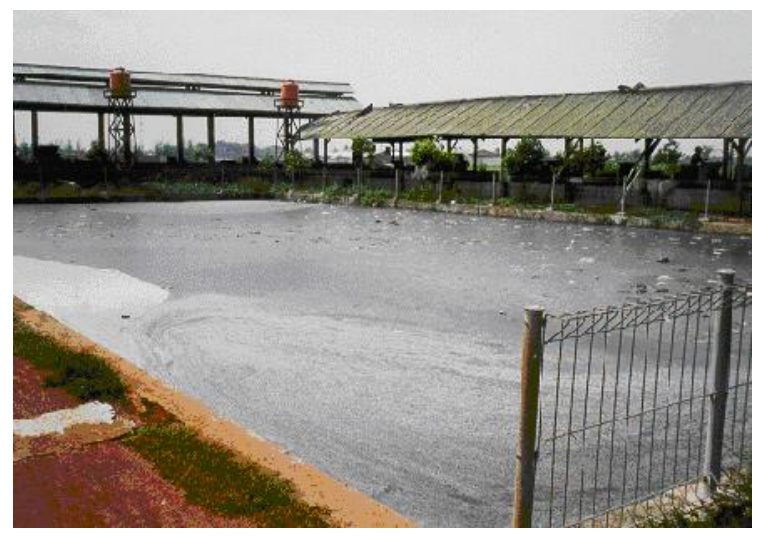

Gambar 5 : Kondisi Air Limbah di Bak Penampung Air Limbah

Pengerajin hanya melakukan proses produksi dengan menggunakan teknologi yang sederhana sekali yang sudah sejak lama mereka gunakan. Mereka tidak memerlukan teknologi canggih untuk membantu pekerjaan mereka karena alasan dana dan SDM yang sangat kurang. Kalaupun mereka membutuhkan informasi tersebut, mereka akan bertanya kepada penyuluh di KOPTI. Sedangkan bagi para penyuluh di KOPTI, informasi teknologi tersebut akan dicari melalui lembaga pemerintah, Universitas atau lembaga penelitian lainnya.

\subsection{Pemilihan Teknologi Pengolahan Air}

Dari hasil kesimpulan sementara yang didapat dari kegiatan survai ke pusat beberapa pengerajin tahu/tempe dan pabrik kecap, maka dapat disimpulkan bahwa teknologi yang sangat diperlukan dan dapat diterapkan untuk membantu memecahkan masalah air bersih dan limbah cair pada industri mereka adalah :

a. Teknologi pengolahan air sumur siap minum.

b. Teknologi pengolahan air untuk air proses pembuatan tempe yang dapat menghilangkan zat besi dan mangan dalam air.

c. Teknologi pengolahan air limbah organik.

d. Teknologi pengolahan limbah padat.

\subsection{Pengumpulan Dokumen Referensi}

Dokumen referensi penunjang terdiri dari artikel-artikel yang ditulis staf kelompok air, laporan-laporan teknis pekerjaan yang menyangkut teknologi pengolahan air dan bukubuku teknologi pengolahan air. Selain itu adalah dokumen yang didapat secara elektronik melalui jaringan Internet. Gambar yang digunakan 
sebagai referensi penunjang diambil langsung dari lokasi tempat paket percontohan unit pengolahan air tersebut dipasang. Sedangkan gambar disain alat, sebagian dibuat oleh beberapa staf kelompok air dan sebagian lagi sebagai hasil modifikasi dari disain yang sudah ada yang disesuaikan dengan kondisi lokasi pemasangan unit pengolahannya.

\subsection{Penyusunan Dokumentasi Teknologi Pengolahan Air}

Untuk memperluas penyebarannya, maka paket teknolog pengolahan air disusun dalam bentuk dokumentasi cetak maupun elektronik. Untuk memperjelas maksud dalam isi dokumentasi, setiap artikel paket teknologi pengolahan air dilengkapi dengan beberapa tabel, disain gambar, foto fisik keadaan sebenarnya dan hasil-hasil percobaan.

Untuk penyusunan dokumentasi elektronik dilakukan dalam format Hypertext dengan menggunakan teknik penulisan HTML (HyperText Markup Language). Setiap artikel paket teknologi pengolahan air dituliskan dalam
Komputer server ini selain digunakan untuk menyajikan informasi teknologi pengolahan air, juga digunakan untuk menyajikan informasi lain tentang keairan, diantaranya : Informasi Database Sumber Daya Air, Informasi jasa pelayanan konsultasi melalui surat elektronik, diskusi online, dan lain-lain.

Agar proses penelusuran informasi dapat dilakukan dengan cepat, maka diperlukan infrastruktur jaringan yang baik di dalam jaringan lokal BPPT sendiri. Pemanfaatan jaringan lokal ini dimaksudkan untuk mengoptimalkan fungsi jaringan elektronik BPPT dengan menambah sumber informasi baru, yaitu informasi teknologi pengolahan air. Selain itu juga agar proses pembaharuan data teknologi tersebut dapat dilakukan dengan cepat karena pengelolaan sumber informasi tersebut langsung ditangani oleh unit kerja teknis di BPPT.

\subsubsection{Disain Sistem Database}

Sistem database server dan program aplikasi penelusuran data dibuat dengan menggunakan bahasa pemrograman HTML, dan

\section{Proses pada komputer server}

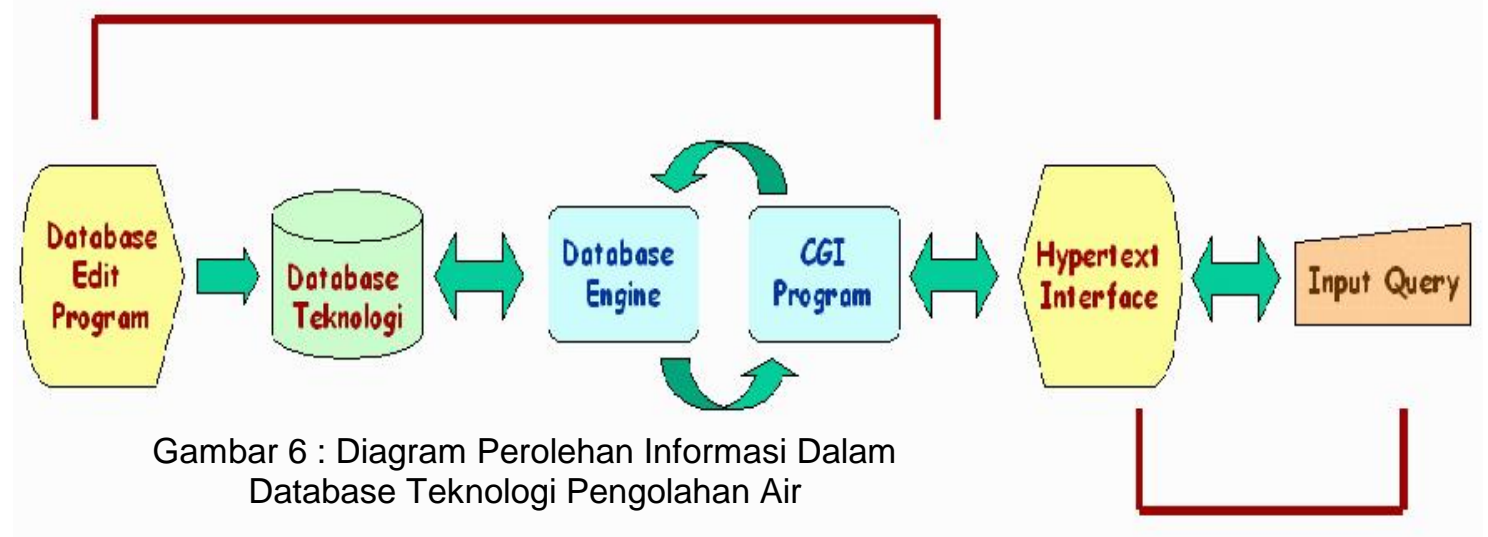

Proses pada komputer client (remote host)

file hypertext yang disimpan ke dalam sebuah direktori sesuai dengan judul artikelnya. Gambargambar diagram dan foto-foto penunjang disimpan dalam format GIF.

\subsection{Pembuatan Database Server dan Aplikasi Penelusuran Informasi}

\subsubsection{Pemanfaatan Infrastruktur Jaringan}

Informasi elektronik paket teknologi pengolahan air diletakkan pada komputer server yang dikelola oleh unit kerja teknis di BPPT, yaitu dengan memanfaatkan infra-struktur jaringan internet yang sudah ada. shell script. Penyajian informasinya dilakukan dengan menggunakan Unix OS yang diinstalasikan pada komputer server dan dibantu dengan program web server yang juga diinstalasikan pada komputer server.

Secara keseluruhan disain database untuk teknologi pengolahan air ini dapat dilihat seperti pada gambar berikut ini, dimana unsurunsur yang membentuk sistem tersebut, yaitu program edit database, file database, database engine, CGI program, dan hypertext interface diletakkan pada komputer server. Hypertext interface yang terdapat dalam server ini dapat diakses oleh komputer lain melalui program web server.

Data-data yang terdapat dalam file database di atas dapat diupdate dengan 
menggunakan program edit database melalui komputer server atau komputer lain dalam jaringan yang sama. Hypertext interface dapat diakses dengan menggunakan program web browser. User pada remote komputer dapat menuliskan query untuk menelusuri informasi data. Database teknologi yang digunakan selain digunakan untuk mendata informasi teknologi pengolahan air, dapat juga digunakan untuk mendata informasi teknologi yang lain. Parameter informasi yang perlu didata dalam database tersebut dibagi ke dalam dua tabel, yaitu :

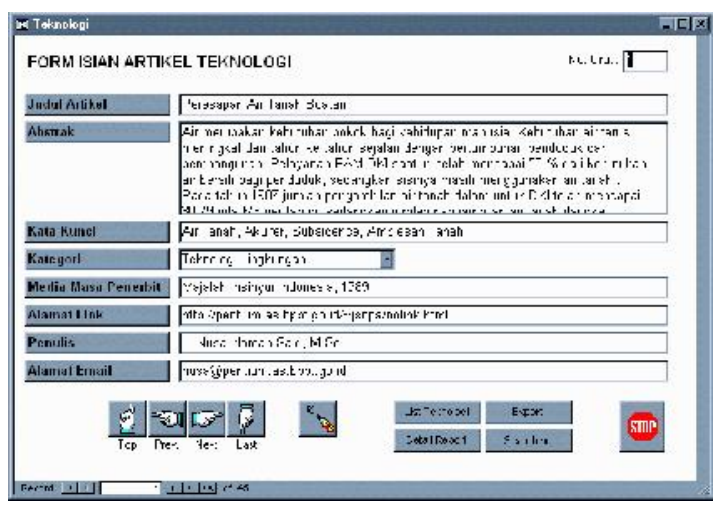

Gambar 7 : Program Edit Database Pada Komputer Lokal.

\section{a. Tabel Kategori}

Tabel ini berisi informasi kategori teknologi, yaitu: Teknologi Lingkungan, Teknologi Pengelolaan Air Bersih, Teknologi Pengolahan Air Limbah, Teknologi Informasi dan Komputer, dan kategori lain-lain untuk paket teknologi selain ini.

Tabel 1. Daftar Field Dalam Tabel Kategori

\begin{tabular}{|l|c|l|}
\hline \multicolumn{1}{|c|}{ NAMA } & JENIS & \multicolumn{1}{c|}{ KETERANGAN } \\
\hline NOMOR & Number & Nomor Urut Pendataan \\
\hline KATEGORI & Text & Kategori Teknologi \\
\hline
\end{tabular}

\section{b. Tabel Teknologi}

Tabel ini berisi informasi tentang artikel/paket teknologi yang mencatat judul teknologi, penulis, abstrak, dan lain-lain.

Tabel 2. Daftar Field Tabel Teknologi

\begin{tabular}{|l|c|l|}
\hline \multicolumn{1}{|c|}{ NAMA } & JENIS & \multicolumn{1}{c|}{ KETERANGAN } \\
\hline NOMOR & Number & Nomor urut pendataan \\
\hline JUDUL & Text & Judul artikel/teknologi \\
\hline ABSTRAK & Memo & Abstrak artikel/teknologi \\
\hline KATAKUNCI & Text & Kata Kunci dari Artikel \\
\hline KATEGORI & Text & Kategori teknologi \\
\hline MEDIAMASA & Text & Media masa penerbit \\
\hline ALAMATLINK & Text & Alamat link direktori/file \\
\hline PENULIS & Text & Nama penulis \\
\hline EMAIL & Text & Alamat email penulis \\
\hline
\end{tabular}

Proses penelusuran data melalui database server dapat dilakukan dengan dua cara, yaitu :

a. Penelusuran secara acak yang dilakukan terhadap seluruh field yang ada di dalam tabel Teknologi.

b. Penelusuran terstruktur dengan memilih bagian field yang akan dicari, misalnya penelusuran terhadap field ABSTRAK, maka program akan mencari informasi dari bagian field ini saja.

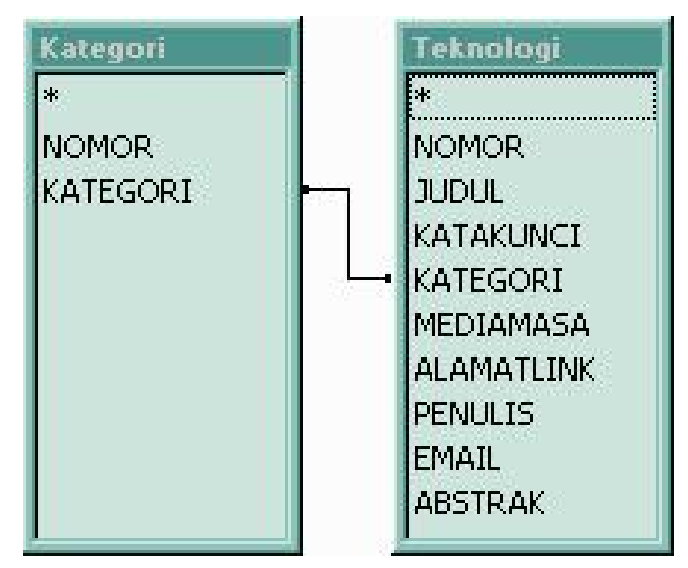

Gambar 8. Relasi Kedua Tabel

\subsubsection{Sistem Operasi}

Sistem operasi yang digunakan untuk mengelola sistem informasi teknologi adalah adalah Unix. Jenis sistem operasi yang digunakan ini akan berpengaruh pada proses penyajian informasi melalui jaringan Internet. Pada jaringan ini, komputer server akan diakses oleh banyak terminal atau komputer lain dari luar. Oleh karena itu penyajian informasi oleh komputer server ini kepada terminal lain yang jumlahnya banyak di seluruh dunia akan dapat dilakukan dengan cepat oleh sistem operasi jaringan seperti Unix atau Microsoft Window NT.

Alasan mengapa memilih Unix OS sebagai sistem operasi komputernya adalah dikarenakan bahwa Unix merupakan sistem operasi yang khusus diciptakan untuk mengoperasikan jaringan global internet. Alasan lain, yaitu jika sebuah komputer tersambung dalam jaringan global internet yang terkenal bebas ini, maka masalah keamanan sistem dan data merupakan masalah yang sangat penting. Sistem operasi Unix mampu memberikan sistem keamanan yang ketat sampai pada level yang terendah sekali pun. Selain itu sistem operasi Unix memberikan kebebasan kepada pemakainya untuk mengembangkan sistem informasinya tanpa memerlukan biaya yang besar. 


\subsubsection{Program Web Server}

Program Cern Httpd 3.0 digunakan sebagai Web Server untuk menyajikan layanan informasi hypertext secara elektronik dan diinstalasikan pada komputer server yang sudah terinstalasi sistem operasi Unix. Program Web server ini dilengkapi dengan utilitas:

- Utilitas proteksi dokumen hypertext agar tidak dapat dibaca oleh remote komputer.

- Utilitas membuat user account untuk menentukan user yang dapat mengakses sebuah informasi hypertext.

- Utilitas membuat informasi hypertext dengan menggunakan clickable map.

- Utilitas mencatat semua remote komputer yang telah mengakses informasi yang ada dalam komputer server, dll.

Struktur direktori program web server yang telah diinstalasikan ke dalam komputer server dalam menyajikan sistem informasi hypertext adalah sebagai berikut :

$\begin{array}{lll}\text { httpd/ } & : \text { root directory program } \\ \text { httpd/bin/ } & : \text { letak path direktori program server } \\ \text { httpd/cgi-bin/ } & : \text { etak program cgi/database engine } \\ \text { httpd/conf/ } & : \text { letak path konfigurasi file } \\ \text { httpd/counter/ } & \vdots \text { letak file akses counter } \\ \text { httpd/docs/ } & : \text { letak file-file dokumen web server } \\ \text { httpd/htdocs/ } & : \text { letak dokumen HTML } \\ \text { httpd/icons/ } & : \text { letak file icon } \\ \text { httpd/logs/ } & : \text { letak file akses log }\end{array}$

\subsubsection{Hypertext Interface dan Database Engine (CGI)}

Selain penyajian informasi dengan teknik penulisan HTML, diperlukan juga teknik pemrograman interface CGI (Common Gateway Interface) yang merupakan interface standar dalam sistem informasi jaringan internet. Programming CGI ini digunakan untuk mengolah data input yang diisi oleh user yang mengakses informasi melalui informasi Web.

Database engine dan CGI yang dikembangkan untuk sistem ini dibuat dengan memanfaatkan fasilitas standar yang terdapat pada sistem operasi Unix, yaitu pemrograman shell script seperti awk, bourne shell dan perl. Baik pemrograman HTML, pemrograman AWK, maupun pemrograman SHELL ini merupakan perangkat lunak standar yang ada dalam setiap sistem Unix, sehingga dalam penggunaannya tidak memerlukan lisensi khusus dari vendornya.

\subsubsection{Metode Akses}

Layanan informasi elektronik untuk teknologi pengolahan air ini hanya dapat diakses oleh jaringan yang mempunyai basis protocol TCP/IP, yaitu melalui jaringan internet online dan metode dialup. Dengan jaringan internet online berarti user dapat mengakses dari mana saja dan kapan saja melalui komputer yang secara langsung tersambung dalam jaringan internet.

\subsection{Instalasi software dan hardware}

Setelah proses pengembangan sistem berjalan kurang lebih $90 \%$, data teknologi dan struktur database yang telah terbuat diinstalasikan berikut software-software pendukung lainnya pada komputer server. Ujicoba akses penelusuran informasi database dilakukan melalui komputer lain baik dari dalam maupun dari luar jaringan intranet BPPT.

Perbaikan terhadap kesalahan-kesalahan (bug) yang terdapat dalam pemrograman database telah dilakukan setelah menganalisa hasil ujicoba akses jaringan.

\section{HASIL YANG DICAPAI}

Kegiatan pengembangan sistem informasi teknologi pengelolahan air telah dapat digunakan untuk menyebarkan paket informasi teknologi khusunya teknologi mengenai pengelolaan air bersih dan pengolahan limbah cair. Sehingga masyarakat, pelaku UKM dan industri dapat mengakses langsung informasi tersebut untuk membantu memecahkan masalah mereka.

Dengan adanya sistem informasi ini BPPT dalam hal ini unit teknis yang melakukan pengkajian tentang teknologi pengelolaan air bersih dan limbah cair dapat secara langsung memperoleh umpan balik yang berupa tanggapan atau kritik terhadap teknologi yang telah diinformasikannya. Sehingga paket teknologi yang akan disebarluaskan berikutnya akan benar-benar menjadi teknologi tepat guna yang memang dibutuhkan oleh masyarakat umum.

Kegiatan pelayanan informasi teknologi pengolahan air dengan percontohan di sentra industri tahu/tempe di Semanan, telah berhasil menyusun paket-paket teknologi tepat guna yang dapat dengan mudah diterapkan oleh pengerajin atau KOPTI untuk memenuhi kebutuhan air minum dan proses produksi tahu/tempe. Salah satu paket teknologi yang telah diterapkan di sentra industri tersebut adalah teknologi pengolahan air sumur untuk kebutuhan air minum. Alat pengolahan air sumur untuk kebutuhan air minum telah dibangun bersama dengan melibatkan pengerajin, pengurus KOPTI dan pemuda karang taruna. 


\section{HAMBATAN}

Yang menjadi hambatan dalam melaksanakan kegiatan pengembangan sistem informasi teknologi pengolahan air ini adalah :

a. Sulitnya mendisain sebuah teknologi pengolahan air bersih atau limbah yang berkapasitas besar dan dapat dibangun atau dikembangkan dengan biaya yang murah.

b. Infrastruktur jaringan lokal BPPT yang sudah padat dan sering tidak aktif, mengakibatkan sulitnya mengakses layanan informasi elektronik yang disajikan oleh BPPT, sehingga proses penelusuran informasi yang dilakukan oleh user dari luar jaringan lokal BPPT banyak mengalami gangguan.

\section{KESIMPULAN}

Untuk melaksanakan kegiatan pengembangan sistem informasi teknologi pengolahan air dengan lingkup percontohan di sentra industri tahu/tempe dapat disimpulkan sebagai berikut :

- Kebutuhan informasi teknologi untuk meningkatkan produktifitas dan kualitas produk sangat diperlukan oleh pengerajin.

- Pengerajin tahu/tempe yang dikelola oleh koperasi mendapatkan informasinya melalui pengurus/penyuluh KOPTI. Penyuluh KOPTI mencarikan informasi secara manual ke beberapa sumber informasi.

- Masalah yang paling mendesak harus diatasi adalah penyediaan air bersih untuk air minum dan proses produksi, serta penanganan limbah cair tahu/tempe.

- Dengan adanya pos pelayanan informasi teknologi di sentra industri tersebut, pengerajin maupun penyuluh KOPTI dapat langsung mencari informasinya. Bimbingan dan konsulasi teknis dapat dilakukan melalui media elektronik.

- Hambatan yang mungkin muncul adalah masalah penguasaan teknologi komputer bagi SDM untuk mencari informasi, masalah perolehan dana untuk menerapkan teknologi yang mereka butuhkan, dan masalah infrastruktur jaringan.

- Sedangkan yang dapat diharapkan dari sistem informasi ini adalah penyebaran informasi produk tahu/tempe dan pengolahannya serta aspek bisnisnya secara elektronik, sehingga dapat menjangkau dunia international.

\section{DAFTAR PUSTAKA}

1. Ir. Nusa Idaman Said, M.Eng., "Unit Alat Pengolah Air Sumur Siap Minum", Makalah pada Forum Orientasi Penerapan dan Pengembangan Teknologi Pembangunan Daerah di Surabaya, 9-14 November 1998.

2. Ir. Nusa Idaman Said, M.Eng., "Teknologi Pengolahan Air Limbah Tahu-Tempe Dengan Sistem Biofilter Anaerob-Aerob", Majalah Analisis Sistem, Nomor: 12 Tahun V, BPPT, Tahun 1998.

3. Heru Dwi Wahjono, B.Eng., "Pengembangan Sistem Informasi Sumber Daya Air", Laporan Teknis 1997-1998, BPPT, Tahun 1998.

4. Jogiyanto HM, "Analisis dan Disain Sistem Informasi Pendekatan Terstruktur", Andi Offset Yogyakarta, Tahun 1989.

5. Sampurna, "Belajar Sendiri Membuat Home Page dengan HTML", PT. Elex Media Komputindo, Tahun 1996.

\section{LAMPIRAN}
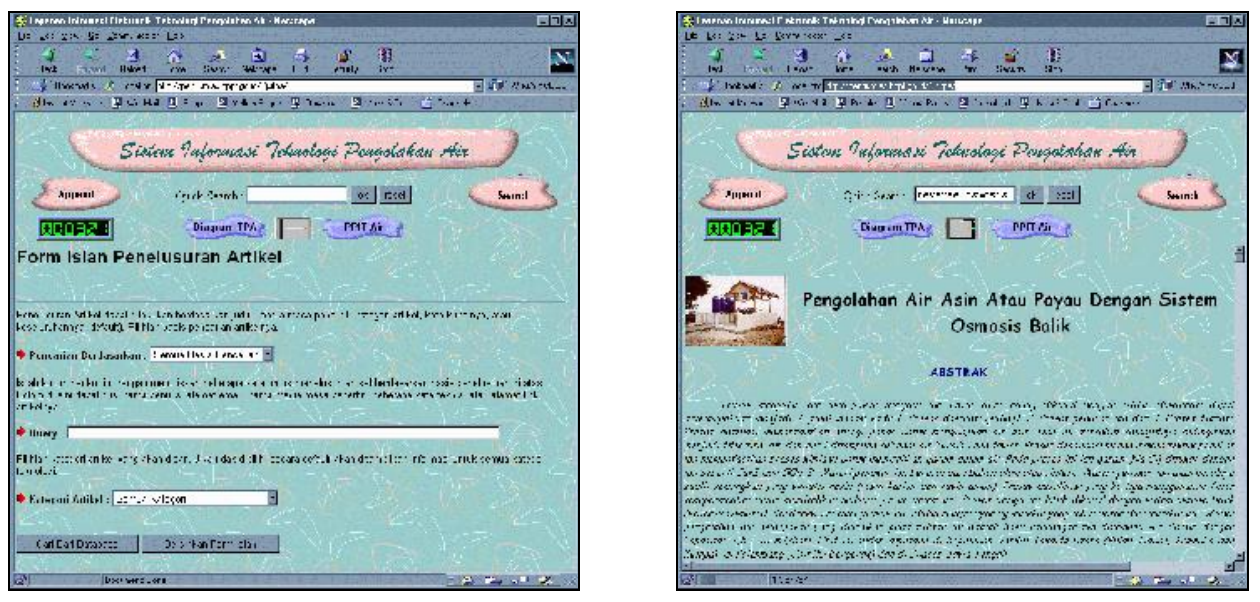

Gambar 9 : Penelusuran Informasi Teknologi. 


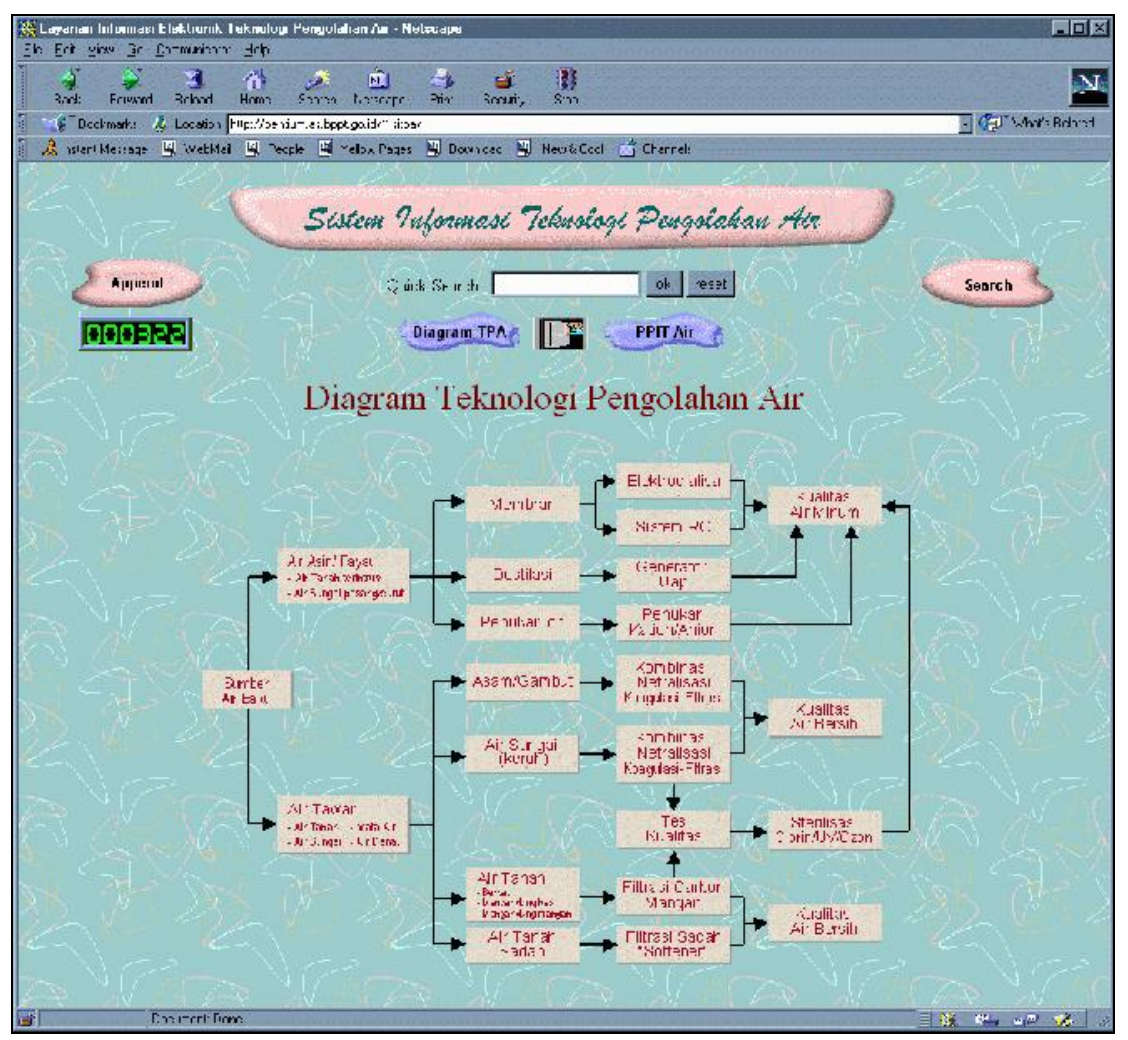

Gambar 10 : Penelusuran Informasi Teknologi dengan Diagram.

Source Code CGI (output.cgi) untuk penelusuran data

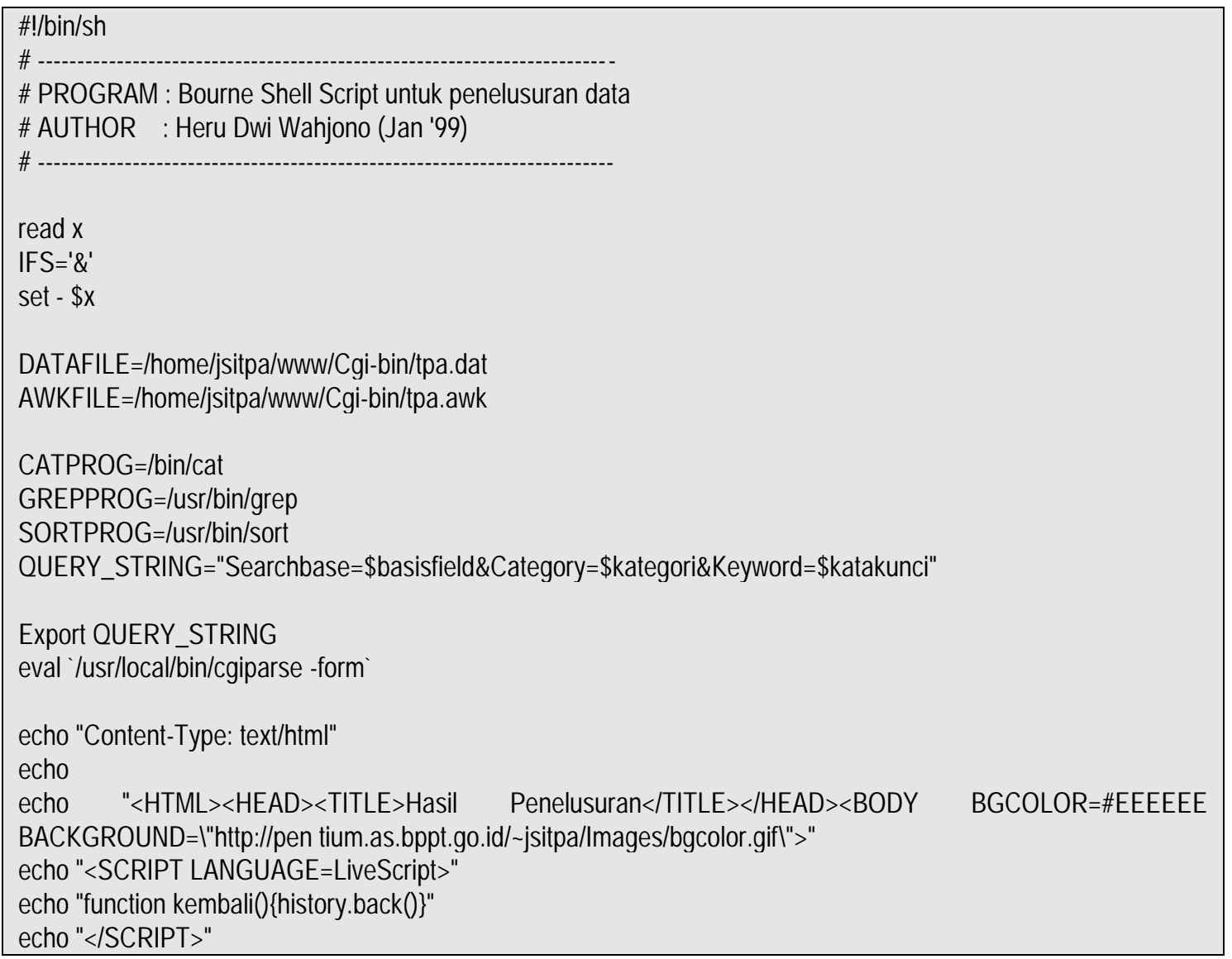




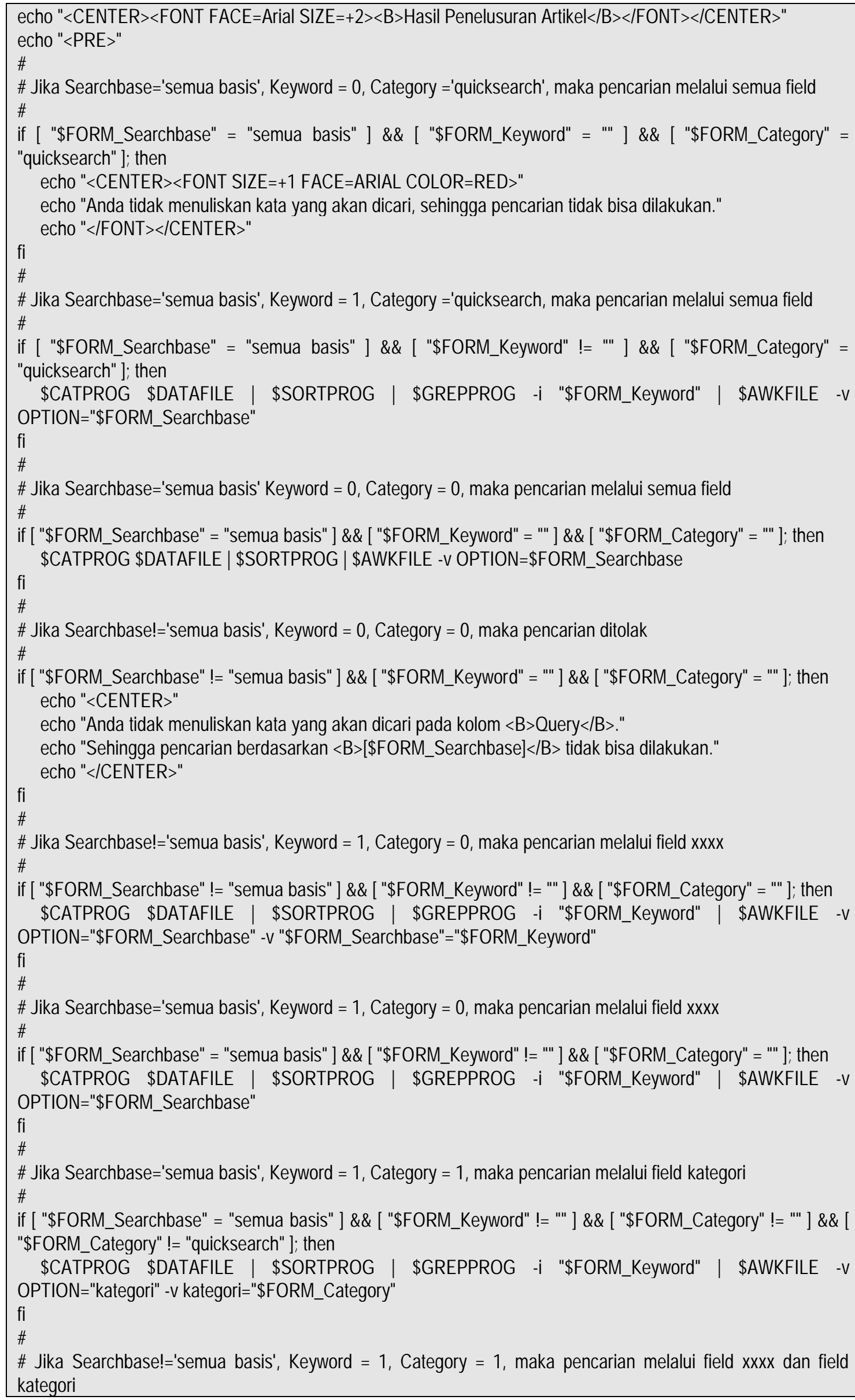




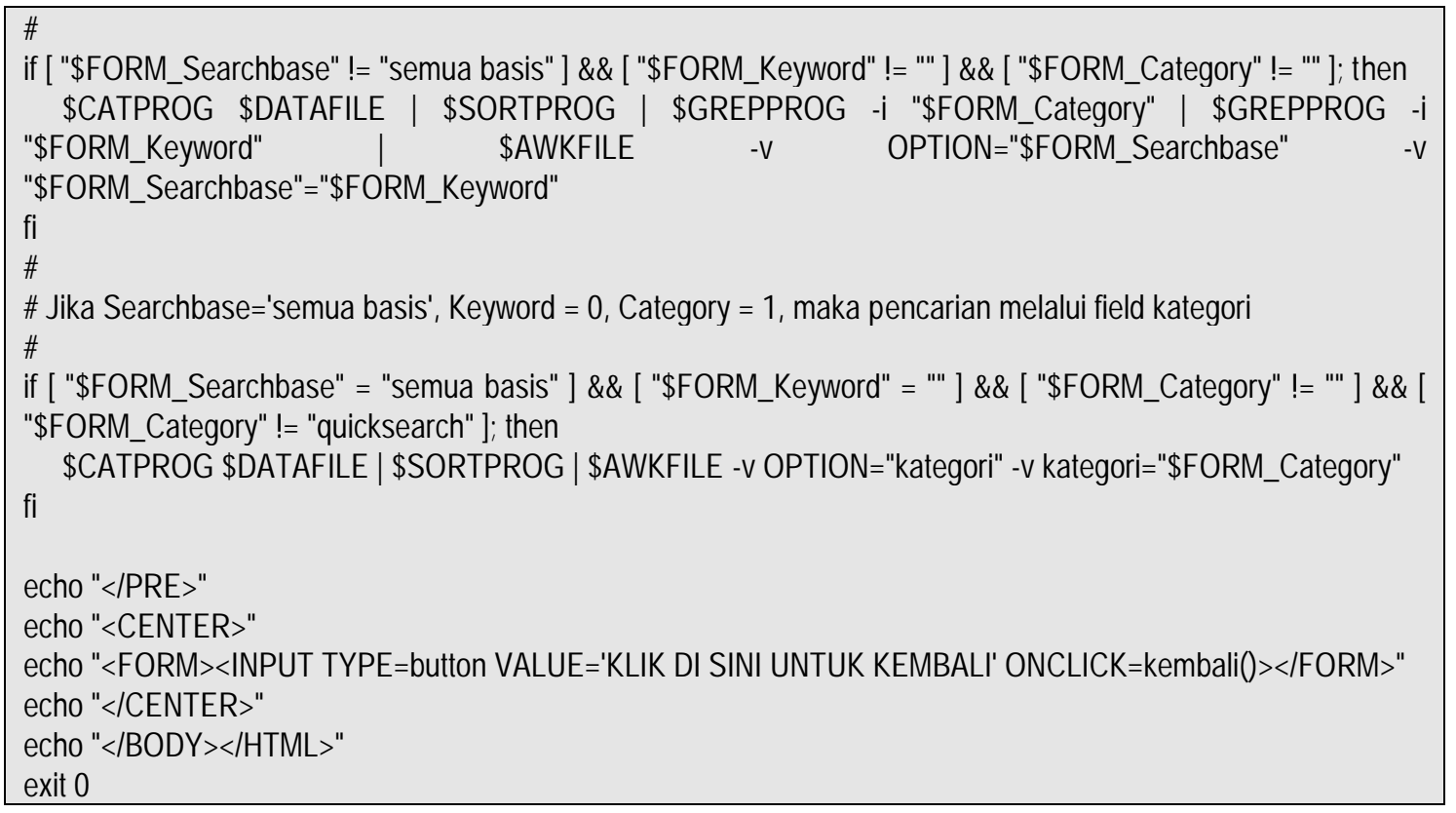

Source Code CGI (output.awk) untuk penampilan kembali hasil penelusuran data

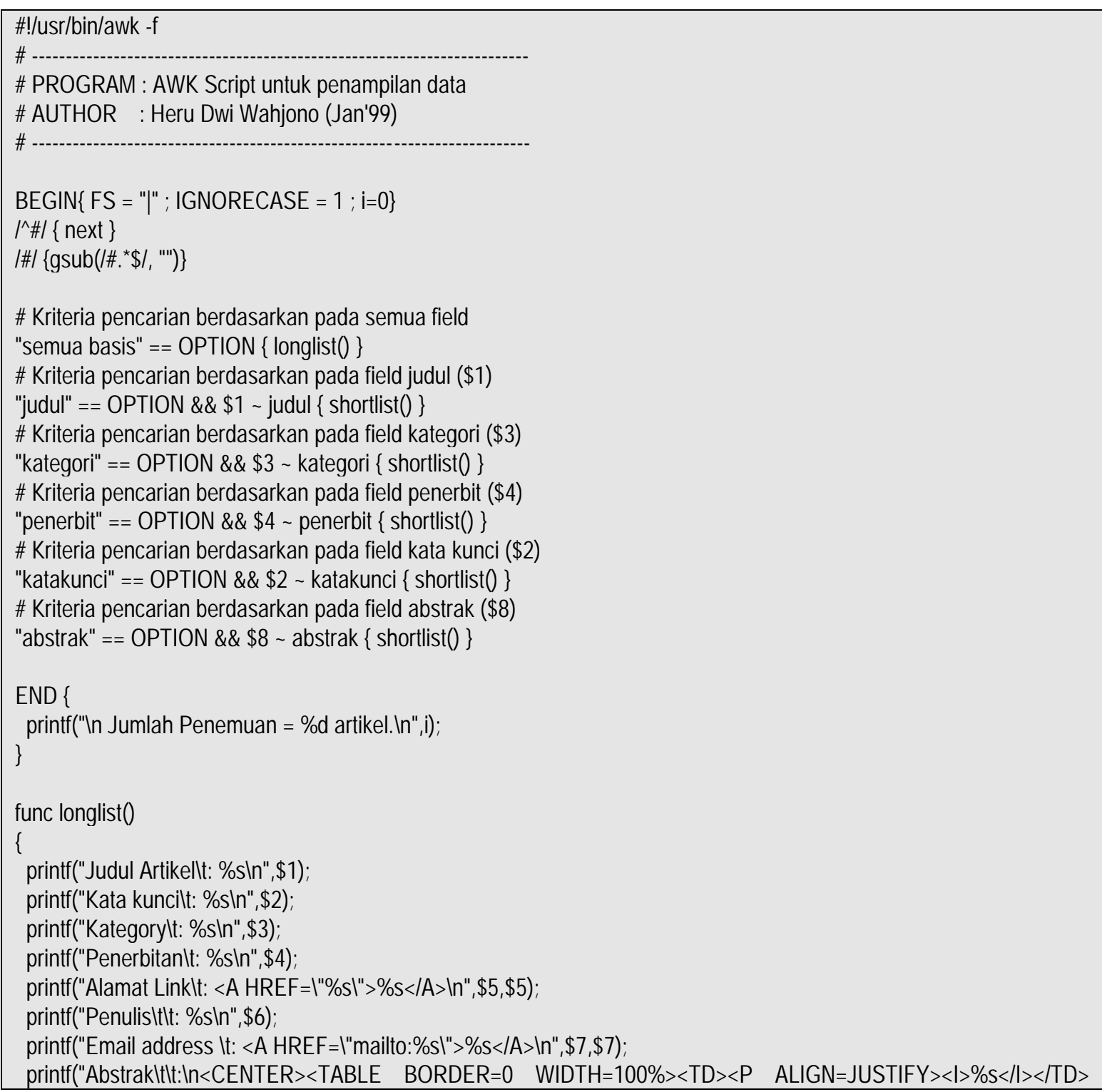




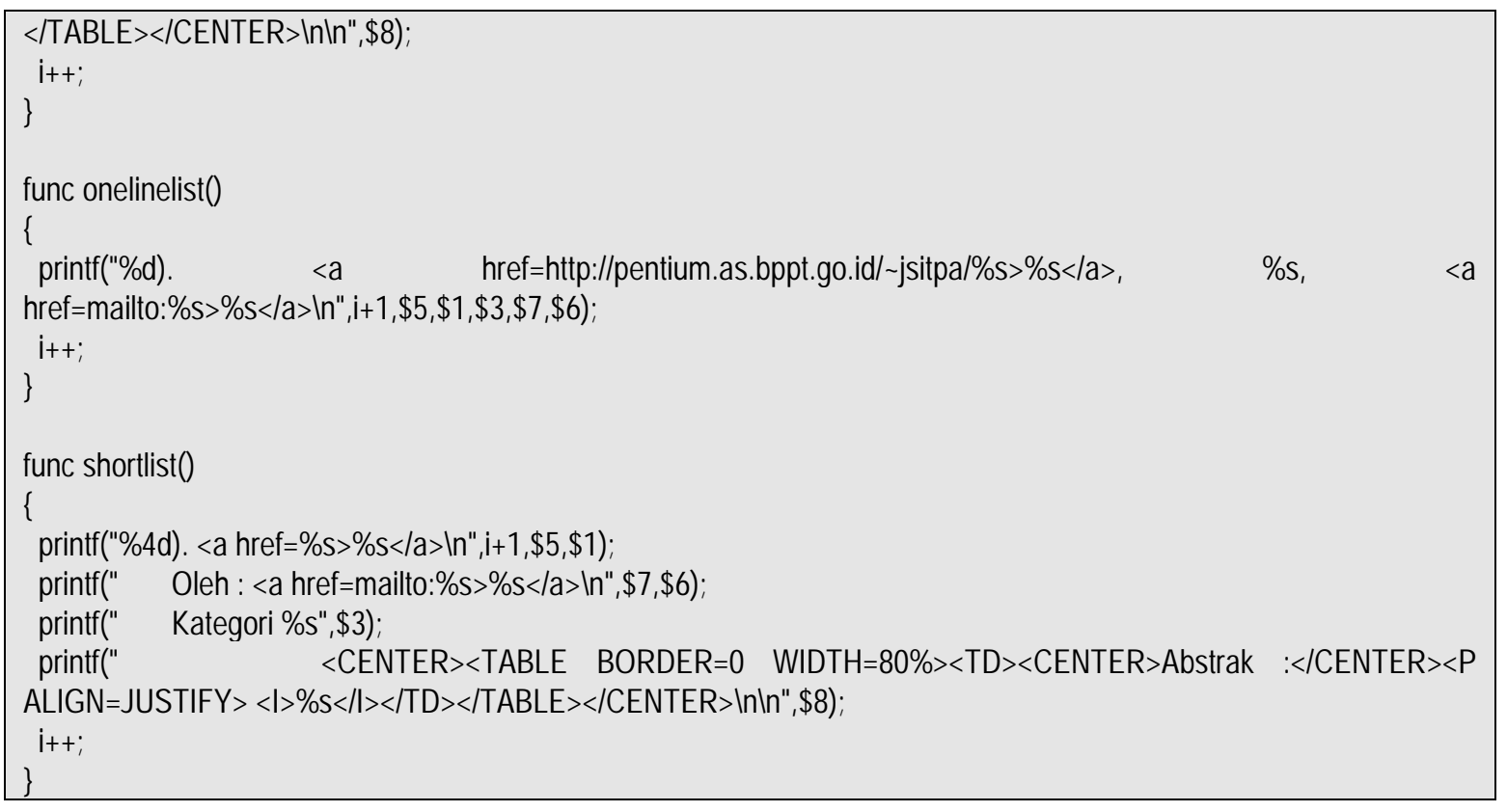

\title{
Contoh isi file database teknologi
}

\author{
\# Data File : Daftar informasi data dan link artikel teknologi air \\ \# Copyright : Heru Dwi Wahjono \\ \# Format : JUDUL,KATAKUNCI,KATEGORI,PENERBITAN,LINK,PENULIS,EMAIL,ABSTRAK
}

Cara Pengolahan Air Sumur Untuk Kebutuhan Air Minum|Mangan, Zat Besi, Filter, Karbon Aktif, Mangan Zeolit, Pengolahan Air Sumur|Teknologi Pengolahan Air Bersih|Pos Pelayanan Informasi Teknologi|http://pentium.as.bppt.go.id/ jsitpa/Artikel/ Akua/index.html|Kelompok Pengkajian Sistem Pengolahan Air|air@pentium.as.bppt.go.id|Air sumur merupakan sumber utama air minum bagi masyarakat yang tinggal di daerah perkotaan. Untuk mendapatkan sumber air tersebut umumnya manusia membuat sumur gali atau sumur pantek. Air tanah sering mengandung zat besi ( $\mathrm{Fe}$ ) dan Mangan (Mn) cukup besar. Adanya kandungan Fe dan Mn dalam air menyebabkan warna air tersebut berubah menjadi kuning-coklat setelah beberapa saat kontak dengan udara. Disamping dapat mengganggu kesehatan juga menimbulkan bau yang kurang enak serta menyebabkan warna kuning pada diding bak serta bercak-bercak kuning pada pakaian. Oleh karena itu menurut PP No.20 Tahun 1990 tersebut, kadar (Fe) dalam air minum maksimum yang dibolehkan adalah 0,3 mg/tt, dan kadar Mangan (Mn) dalam air minum yang dibolehkan adalah 0,1 mg/tt. Untuk mengatasi masalah tersebut, maka Kelompok Pengkajian Sistem Pengelolaan Air, Kedeputian Bidang Analisis Sistem, BPP Teknologi telah dirancang suatu unit pengolahan air sumur yang dapat langsung diminum tanpa dimasak terlebih dahulu. Unit pengolahan tersebut terdiri dari antara lain : pompa air baku, filter bertekanan, filter mangan zeolit, filter karbon aktif, cartridge filter dan sterilisator ultra violet. Unit alat tersebut dapat dirancang sesuai dengan kapasitas yang diinginkan.

Pengolahan Air Sungai / Gambut Sederhana|Gambut, Netralisasi, Aerasi, Koagulasi|Teknologi Pengolahan Air Bersih|Pos Pelayanan Informasi Teknologi|http://pentium.as.bppt.go.id/ -jsitpa/Artikel/Gambut/index.htm||Kelompok Pengkajian Sistem Pengolahan Air|air@pentium.as.bppt.go.id|Dalam rangka penyediaan air bersih pedesaan, sering terdapat kendala misalnya, lokasi pemukiman yang berjauhan, sehingga jika dibangun sistem pengolahan yang terpadu dengan sistem perpipaan membutuhkan biaya yang sangat besar. Untuk mengatasai hal tersebut, dapat dilakukan dengan cara pengolahan sederhana untuk skala rumah tangga. Tulisan ini membahas tentang cara pengolahan air sederhana, khususnya untuk mengolah air gambut. Cara ini merupakan salah satu alternatif untuk memenuhi kebutuhan air bersih di pedesaan dengan cara yang murah dan sederhana. 